\title{
EA29
}

\section{Tanzania Block 2: From Discovery to} Development

\section{T. John* (Statoil), S. Solymar (Statoil) \& L. Jetlund Hansen (Statoil)}

\section{SUMMARY}

A total of 8 discoveries have been made in Tanzania Block 2. Discoveries have been made in Cretaceous, Paleogene and Miocene stratigraphic levels. Despite many similarities, the discoveries all have their individual challenges, including facies distributions, reservoir properties and steep seabed canyons. Several of the discoveries are now being evaluated for development. The full value chain development project is expected to comprise gas extraction through subsea wells and a subsea production system to an onshore LNG plant. 


\section{Introduction}

Statoil was awarded Block 2 in 2007 as operator and in 2010 ExxonMobil Exploration and Production Tanzania Limited became its partner with 35\%. The first 3D seismic data was acquired in 2009 covering the area around the Sea Gap strike slip fault system and its associated popup structures and pull-apart basins. A total of 8 discoveries have been made during the drilling campaign from 2012 to 2015. In addition to the discovery wells, the drilling campaign included several appraisal wells and one DST. The discoveries in Tanzania Block 2 are located some $100 \mathrm{~km}$ offshore Tanzania at a water depth of approximately $2500 \mathrm{~m}$.

\section{Theory}

The geological setting has persisted since at least the Jurassic, depositing deep water turbidite systems through time. At present day, the sea floor still shows evidence of a highly erosive system creating steep canyons, contributing to challenging development solutions.

Discoveries have been made in Cretaceous, Paleogene and Miocene stratigraphic levels. Deposition has been strongly influenced by tectonic activity along the Sea Gap strike slip fault system. Presence of pop-up highs, pull-apart basins, development of faults and possibly mounding affected the accommodation space and guided the reservoir deposition. Despite many similarities, the discoveries all have their individual challenges, including facies distributions and reservoir properties.

Several of the discoveries are now being evaluated for development but are at different maturity levels. The understanding of the discoveries is being matured through comprehensive geological and geophysical work as well as dynamic understanding based on simulated reservoir models. The full value chain development project is expected to comprise gas extraction through subsea wells and a subsea production system to an onshore LNG plant. 